\title{
Peptide Dendrimers: From Enzyme Models to Antimicrobials and Transfection Reagents
}

\author{
Jean-Louis Reymond*
}

\begin{abstract}
Aiming at studying cooperativity effects between amino acids in easily accessible protein models, we have explored the chemistry of peptide dendrimers, which we obtain as pure products by solid-phase peptide synthesis using a branching diamino acid such as lysine at every second or third position in a peptide sequence, followed by reverse-phase HPLC purification. This article reviews discoveries driven by combinatorial library synthesis and screening, including enantioselective esterase and aldolase enzyme models, cobalamin binding and peroxidase dendrimers, glycopeptide dendrimer biofilm inhibitors and their X-ray crystal structures as complexes with lectins, antimicrobial peptide dendrimers active against multidrug resistant Gram-negative bacteria, and transfection reagents for siRNA and CRISPR-Cas9 plasmid DNA. Latest developments include cheminformatics and artificial intelligence for exploring the peptide chemical space, and the principle of stereorandomization to understand the role of peptide chirality in activity.
\end{abstract}

Keywords: Antimicrobials · Dendrimers · Enzyme models · Peptides · Transfection reagents

\section{Introduction}

One goal of bioorganic chemistry is to discover how to combine simple building blocks to form synthetic macromolecules displaying emergent properties. In our previous work with catalytic antibodies, we observed enzyme-like catalysis in substrate binding sites usually equipped with a single catalytic residue, for instance a hydrogen-bonded aspartate activating a water molecule for enantioselective protonation, ${ }^{[1]}$ or a tryptophan activating the substrate by $\pi$-stacking for retro-Diels-Alder catalysis. ${ }^{[2]}$ As a follow-up, we envisioned to search for enzyme-like cooperative effects involving multiple amino acids by enforcing spatial proximity between catalytic residues using a molecular tree, or dendrimer. At the outset of this project, the concept of dendrimers as molecular trees to mimic proteins and enzymes was well established but had not been attempted with amino acids.

In contrast to most dendrimers prepared as mixtures using polymer chemistry approaches, we synthesized peptide dendrimers as pure products using solid-phase peptide synthesis (SPPS) followed by reverse-phase HPLC purification. To obtain dendrimers, we modified the SPPS protocol by inserting a branching diamino acid (diaminopropanoic acid or lysine) at every second or third residue in a peptide sequence, which created successive dendrimer generations doubling the number of growing peptide chains at each branching residue. ${ }^{[3]}$ This overview summarizes the project from initial enzyme model studies to latest biomedical applications, which has involved many $\mathrm{PhD}$ students and post-docs as well as PD Dr. Tamis Darbre and Dr. Sacha Javor as co-supervisors.

\section{Peptide Dendrimer Enzyme Models}

In an initial study featuring the catalytic triad (aspartic acid, histidine and serine) as building blocks, ${ }^{[3]}$ we discovered partly enantioselective peptide dendrimers hydrolyzing chiral cationic quinolinium esters with a catalytic site at the dendrimer core. ${ }^{[4]}$ The reaction mechanism involved cooperativity between aspartates for electrostatic substrate binding and a histidine acting as general base for ester bond cleavage. Screening combinatorial libraries ${ }^{[5]}$ uncovered further esterase dendrimers with a single catalytic histidine at the core, which was assisted by two cationic arginines for electrostatic binding to anionic pyrene trisulfonate ester substrates, however again with only partial enantioselectivity. ${ }^{[6,7]}$ We further exploited the idea of an enzyme-like catalytic site at the dendrimer core to obtain a dendrimer binding to cobalamin via a cysteine residue ${ }^{[8]}$ and a peroxidase dendrimer featuring a mono-coordinated Fe(II)-bipyridine at its core. ${ }^{[9]}$

Our most active catalysts, however, turned out to be typical dendrimers exploiting cooperativity between multiple catalytic residues in the dendrimer branches. The best examples involved histidines for ester hydrolysis, ${ }^{[10]}$ and $\mathrm{N}$-terminal prolines for enantioselective aldol catalysis (Fig. 1), ${ }^{[11,12]}$ resulting in catalytic efficiencies per residue surpassing linear peptides. ${ }^{[13]}$ However, stereoselectivity remained difficult to control in these multivalent systems.

\section{Glycopeptide Dendrimers and Lectin Crystallography}

By capping the multiple N-termini of our peptide dendrimers with glycosylated carboxylic acids as the last SPPS coupling step, we obtained multivalent glycopeptide dendrimers enabling us to use cooperativity to bind to multivalent carbohydrate receptors. ${ }^{[14]}$ While our first application aimed to deliver colchicine to cancer cells, ${ }^{[15,16]}$ we obtained the most interesting results with peptide dendrimers displaying fucose or galactose to target the virulence factors lectins LecB or LecA of the bacterium Pseudomonas aeruginosa. These glycopeptide dendrimers displayed good biofilm inhibition and dispersal activities. ${ }^{[17,18]}$ 


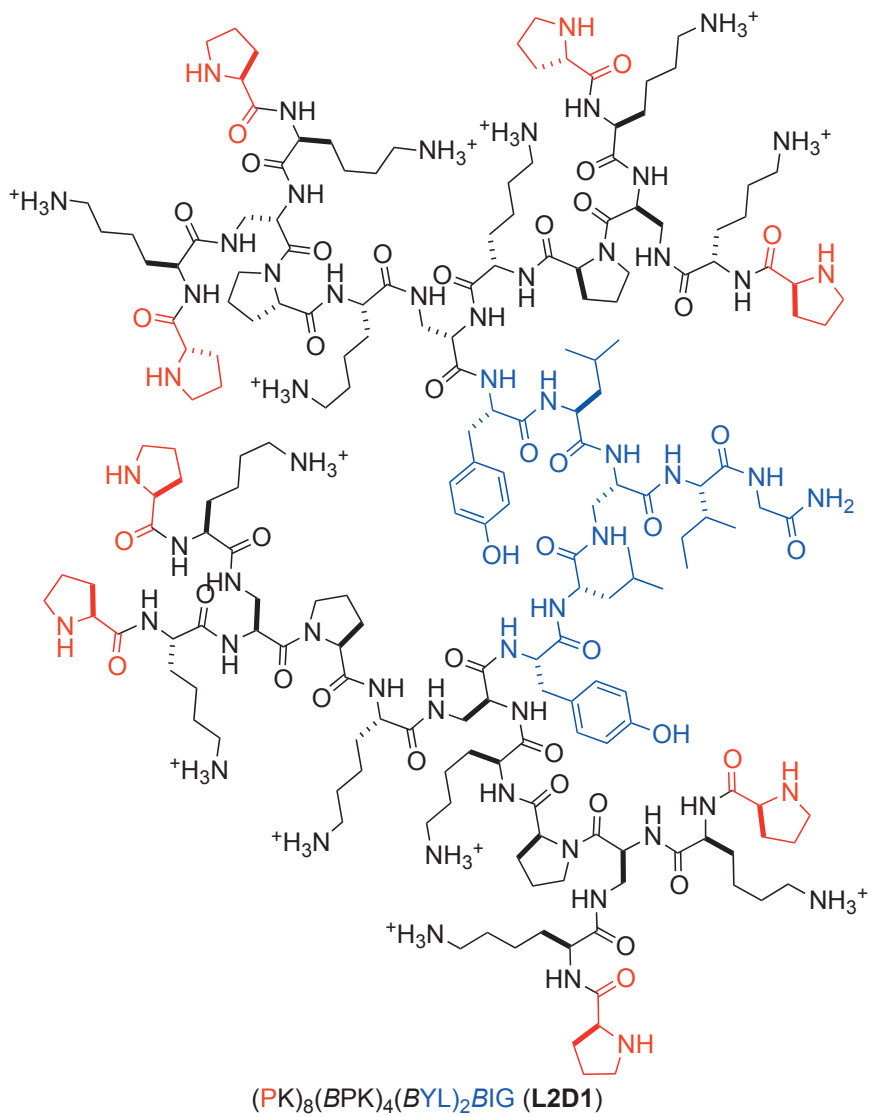<smiles>O=Cc1ccc([N+](=O)[O-])cc1</smiles><smiles>CC(=O)CC(O)c1ccc([N+](=O)[O-])cc1</smiles>

$61 \%$ ee

Fig. 1. Aldolase peptide dendrimer L2D1 discovered by Jacob Kofoed. ${ }^{[11]}$

In the course of these studies, we learned to perform X-ray crystallography of lectins with bound ligands in collaboration with Prof. Achim Stocker in Bern, ${ }^{[19]}$ which led us to the first $\mathrm{X}$-ray crystal structures of peptide dendrimers in the form of complexes with LecB (PDB 5D2A and 6S5S).[20,21] The same approach allowed us to characterize cyclic antimicrobial peptides with mixed D,L-chirality (PDB 5NF0), ${ }^{[22]}$ to obtain the first $\mathrm{X}$-ray crystal structures of short $\alpha$-helical antimicrobial peptides (AMPs, PDB 6Q86), ${ }^{[23]}$ and very recently to characterize the first X-ray crystal structures of an $\alpha$-helical peptide with mixed chirality consisting of only natural residues in both bicyclic and linear forms (PDB 6YOU, 7NEW). [24]

In the structure of peptide dendrimer SBD8 in complex with $\mathrm{LecB}$, the dendrimer forms dimers interacting with each other via hydrophobic contacts, and with the lectin via one of its two anchoring fucose residues (Fig. 2). Strikingly, only 33\% of the residues in dendrimer SBD8 form backbone H-bonds, a feature suggested by molecular dynamics (MD) simulations of several other peptide dendrimers and which contrasts with folded proteins and peptides where approximately $70 \%$ of the residues form backbone H-bonds. Despite the low percentage of backbone H-bonds in peptide dendrimer SBD8, MD simulations show that the X-ray conformation is stable both as monomer and as dimer. This conformational stability might explain the success of crystallization and is probably the exception rather than the rule for peptide dendrimers considering that crystallization attempts entirely failed with many other peptide dendrimers as LecB complexes, as pure peptides or as racemates.
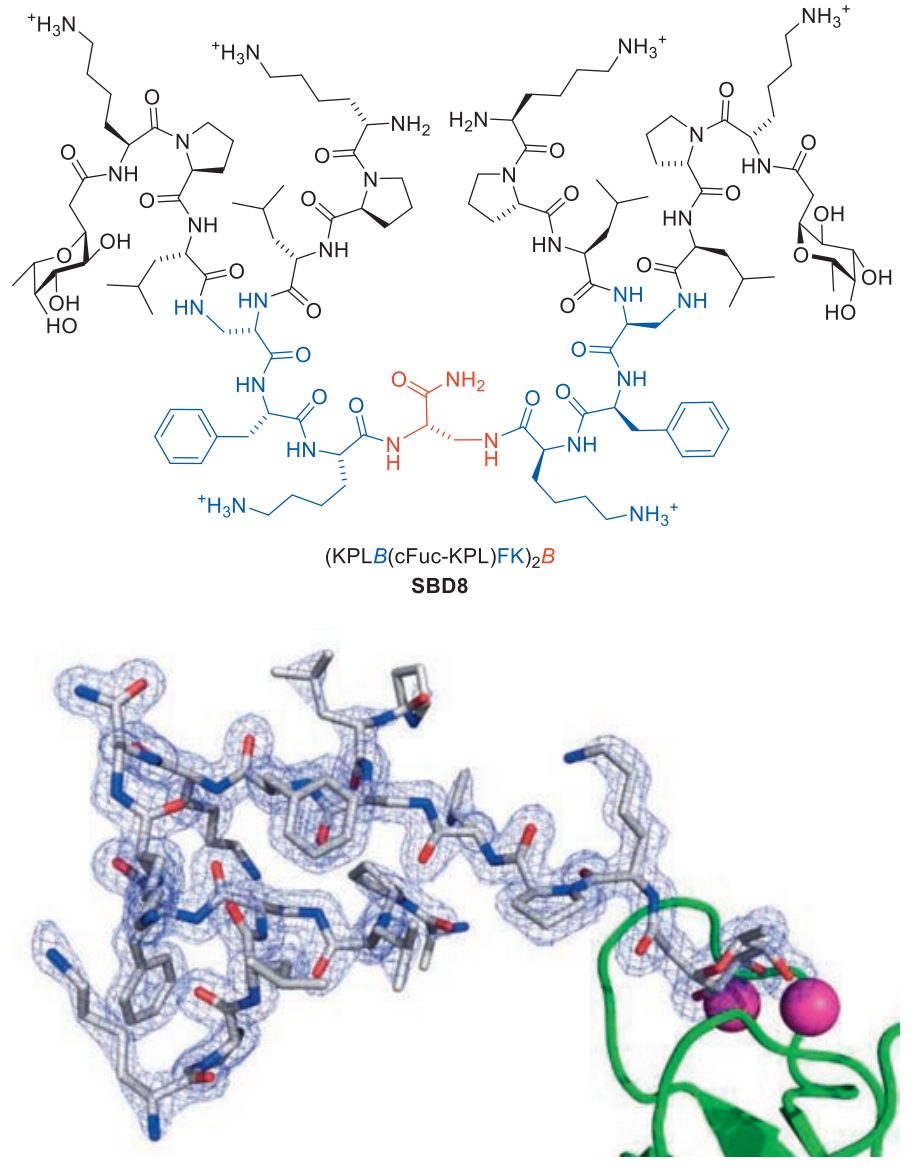

Fig. 2. Peptide dendrimer SBD8 and its X-ray crystal structure as LecB complex (PDB 6S5S) designed and solved by Stéphane Baeriswyl. ${ }^{[21]}$

\section{Antimicrobial Peptide Dendrimers}

In a control experiment exposing a catalytic peptide dendrimer combinatorial library[25] to a screening protocol for discovering antimicrobial cyclic peptides, ${ }^{[26]}$ we discovered polycationic peptide dendrimers with a membrane disruptive antibacterial activity. ${ }^{[27]}$ Further optimization by sequence design resulted in antimicrobial peptide dendrimers (AMPDs) able to kill multidrug resistant Gram-negative bacteria such as Pseudomonas aeruginosa and Acinetobacter baumannii, which we investigated in collaboration with Dr. Thilo Köhler and Prof. Christian van Delden at the University Hospital in Geneva. ${ }^{[28]}$ Our AMPDs exploit the cooperativity between multiple cationic and hydrophobic groups in the dendrimer branches to permeabilize the outer and inner membrane of bacteria, ${ }^{[29]}$ enabling synergistic effects with other antibiotics, ${ }^{[30]}$ while eliciting only very low resistance. ${ }^{[31]}$ We have further optimized AMPDs for broader activity using combinatorial chemistry ${ }^{[32]}$ and chemical space guided design. ${ }^{[33,34]}$

Circular dichroism (CD) spectra show that, similar to linear AMPs, AMPDs are typically unordered in water and $\alpha$-helical in the membrane environment. However, experiments with stereorandomized peptides, which we prepare as pure products containing all possible diastereomers using racemic amino acids in SPPS, show that our AMPDs retain their antibacterial activity upon stereorandomization, while showing strongly reduced cell toxicity and hemolysis. ${ }^{[35]}$ In the case of AMPD T25 partial stereorandomization of the dendrimer core ( $s r$-T25b) suppresses $\alpha$-helical folding, which retains bacterial membrane disruption and bacterial killing, but abolishes eukaryotic membrane disruption, cell toxicity and hemolysis (Fig. 3). We are currently exploring the effects of stereorandomization on different peptide-related compounds as a potential general tool for improving their bioactivity profile. 


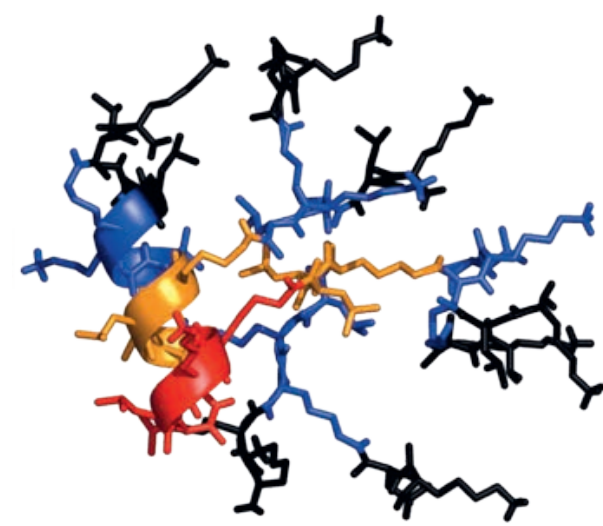

L-T25: $(\mathrm{KL})_{8}(\mathrm{KKL})_{4}(\mathrm{KLL})_{2} \mathrm{KKLL}$ (L-enantiomer)

D-T25: $(\mathrm{kl})_{8}(\mathrm{kkl})_{4}(\mathrm{kll})_{2} k \mathrm{kll}$ (D-enantiomer) rac-T25 (1:1 mixture of L-T25 and D-T25) $s r-\mathrm{T} 25:(\mathrm{KL})_{8}(K K L)_{4}(K L L)_{2} K K L L$ (all residues stereorandomized) sr-T25a: $(\mathrm{KL})_{8}(\mathrm{KKL})_{4}(\mathrm{KLL})_{2} \mathrm{KKLL}$ (G2 and $\mathrm{G} 3$ stereorandomized sr-T25b: $(\mathrm{KL})_{8}(\mathrm{KKL})_{4}(\mathrm{KLL})_{2} K \mathrm{KLL}(\mathrm{GO}$ and $\mathrm{G} 1$ stereorandomized)

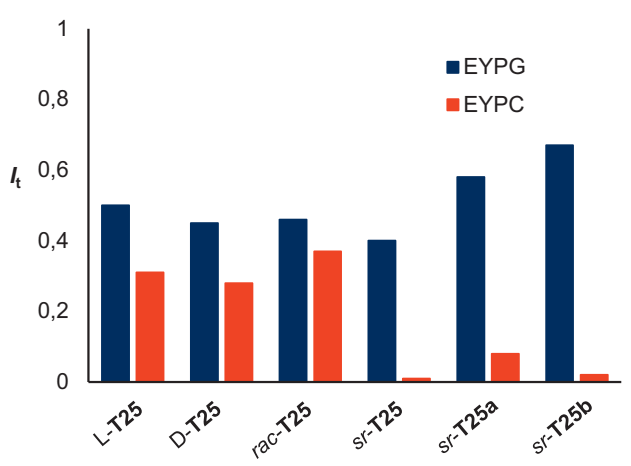

Fig. 3. MD simulations of AMPD T25 performed by Sacha Javor show the $\alpha$-helical fold. The effect of full and partial stereorandomization of T25 on disrupting vesicles made of bacterial (EYPG) or eukaryotic (EYPC) lipids was investigated by Thissa Siriwardena. ${ }^{[3]}$

The striking lesson from our various optimization campaigns with AMPDs is that their antibacterial activity spectrum, their cellular toxicity and their proteolytic stability strongly depends on their amino acid sequence, branching structure and stereochemistry. Even single residue changes at the dendrimer core and inner branches, which only account for a small fraction of the dendrimer, can strongly affect their activity. While AMPDs do not aggregate like the related transfection dendrimers described in the next section, we recently discovered that their antibacterial activity can be preserved at the acidic $\mathrm{pH}$ of 5.5 typical of biofilms and human skin by removing their eight low $\mathrm{p} K$ amino termini. ${ }^{[43]}$ In the same study, we discovered that AMPD activity strongly increases in slightly alkaline media corresponding to chronic wounds to include Klebsiella pneumoniae as well as methicillin resistant Staphylococcus aureus. We are currently fine-tuning the properties of our best AMPDs by altering their sequence and stereochemistry to improve their in vivo toxicity, half-life and antibacterial activity profile aiming for a clinical candidate.

\section{Peptide Dendrimers as Transfection Reagents for DNA and siRNA}

In the course of exploring the potential of peptide dendrimers as cell penetrating peptides, ${ }^{[36,37]}$ a collaboration with Prof. Florian Hollfelder in Cambridge UK led us to discover that our peptide dendrimers can act as transfection reagents for DNA and siRNA when co-administered with cationic lipids. ${ }^{[38,39]}$ In a follow-up study, we introduced a hydrophobic dendrimer core to trigger $\mathrm{pH}$-dependent aggregation of the dendrimer to form nucleic acid binding nanoparticles and obtained highly efficient peptide den- drimer single component transfection reagents for siRNA ${ }^{[40,41]}$ and CRISPR-Cas9 plasmid DNA (Fig. 4). ${ }^{[42]}$ Note that despite their structural resemblance to the AMPDs discussed above, our transfection dendrimers do not kill bacteria. Compared to commercial transfection reagents such as lipofectamine, our transfection dendrimers show lower cellular toxicity and offer an entirely well-defined alternative that is much more stable upon storage and provides much better reproducible transfection efficiencies.
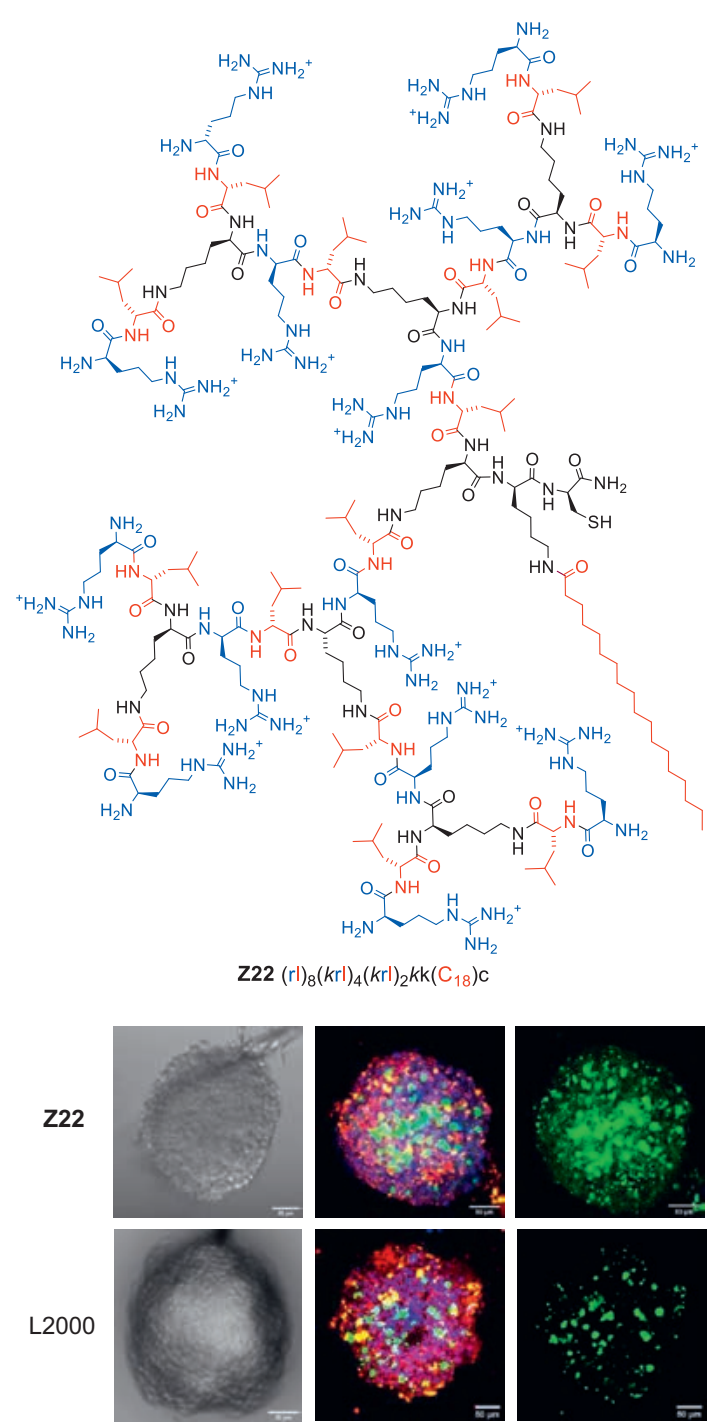

Fig. 4. Dendrimer Z22 designed by Susanna Zamolo transfects tumor spheroids with a large CRISPR-Cas9 plasmid, detected by GFP expression, much more efficiently than the commercial reagent L2000. ${ }^{[42]}$

\section{Conclusion and Outlook}

Dendrimer SPPS has turned out to be reliable with up to three successive branching points, or generations, to form so-called 'third generation' dendrimers with eight amino termini, up to 50 residues and a molecular weight up to $5 \mathrm{kDa}$ depending on the length of each generation (usually 1-3 residues). We were recently able to reduce reaction times and increase isolated yields using optimized reagents and high temperature syntheses. The dependence of peptide dendrimer properties on amino acid sequence and stereochemistry allows for straightforward trial-and-error discovery and optimization cycles, optionally including combinatorial libraries. To assist and extend the scope of this approach, we are currently exploring the concept of the peptide chemical space, ${ }^{[44]}$ including molecular fingerprints, genetic algorithms 
and machine learning methods tested for proteins, ${ }^{[45]}$ macromolecules, ${ }^{[46,47]}$ linear ${ }^{[48]}$ and bicyclic peptides. ${ }^{[49,50]}$ In terms of activity types, our current focus is on antimicrobials and immunomodulatory dendrimers.

\section{Acknowledgements}

This work is currently supported financially by the Swiss National Science Foundation Grant no. 200020_178998 and 407240_167048 and by the European Research Council Grant no. 885076. The author thanks all the group members and collaborators who dedicated their creativity, enthusiasm and hard work to the peptide dendrimer project.

Received: April 13, 2021

[1] L. Zheng, U. Baumann, J. L. Reymond, Proc. Natl. Acad. Sci. USA 2004, 101, 3387, https://doi.org/10.1093/nar/gnh110

[2] M. Hugot, N. Bensel, M. Vogel, M. T. Reymond, B. Stadler, J. L. Reymond, U. Baumann, Proc. Natl. Acad. Sci. USA 2002, 99, 9674, https://doi.org/10.1073/pnas.142286599

[3] A. Esposito, E. Delort, D. Lagnoux, F. Djojo, J. L. Reymond, Angew. Chem. Int. Ed. 2003, 42, 1381, https://doi.org/10.1002/anie.200390354

[4] C. Douat-Casassus, T. Darbre, J. L. Reymond, J. Am. Chem. Soc. 2004, 126, 7817, https://doi.org/10.1021/ja049276n

[5] A. Clouet, T. Darbre, J.-L. Reymond, Angew. Chem. Int. Ed. 2004, 43, 4612, https://doi.org/10.1002/anie.200460177

[6] S. Javor, E. Delort, T. Darbre, J. L. Reymond, J. Am. Chem. Soc. 2007, 129 , 13238, https://doi.org/10.1021/ja074115f

[7] N. Maillard, T. Darbre, J. L. Reymond, J. Comb. Chem. 2009, 11, 667, https://doi.org/10.1021/co200006z

[8] P. Sommer, N. A. Uhlich, J. L. Reymond, T. Darbre, ChemBioChem 2008, 9 , 689, https://doi.org/10.1002/cbic.200700606

[9] P. Geotti-Bianchini, T. Darbre, J. L. Reymond, Org. Biomol. Chem. 2013, 11, 344, https://doi.org/10.1039/С2ОВ26551F

[10] E. Delort, T. Darbre, J. L. Reymond, J. Am. Chem. Soc. 2004, 126, 15642, https://doi.org/10.1021/ja044652p

[11] J. Kofoed, T. Darbre, J. L. Reymond, Org. Biomol. Chem. 2006, 4, 3268, https://doi.org/10.1039/B607342E

[12] N. A. Uhlich, T. Darbre, J.-L. Reymond, Org. Biomol. Chem. 2011, 9, 7071, https://doi.org/10.1039/C1OB05877K

[13] R. Biswas, N. Maillard, J. Kofoed, J. L. Reymond, Chem. Commun. 2010, 46, 8746, https://doi.org/10.1039/C0CC02700F

[14] E. Kolomiets, E. M. Johansson, O. Renaudet, T. Darbre, J. L. Reymond, Org. Lett. 2007, 9, 1465, https://doi.org/10.1021/o1070119d

[15] D. Lagnoux, T. Darbre, M. L. Schmitz, J. L. Reymond, Chem. Eur. J. 2005, 11, 3941, https://doi.org/10.1002/chem.200401294

[16] E. M. Johansson, J. Dubois, T. Darbre, J. L. Reymond, Bioorg. Med. Chem. 2010, 18, 6589, https://doi.org/10.1016/j.bmc.2010.04.026

[17] E. M. Johansson, S. A. Crusz, E. Kolomiets, L. Buts, R. U. Kadam, M. Cacciarini, K. M. Bartels, S. P. Diggle, M. Camara, P. Williams, R. Loris, C. Nativi, F. Rosenau, K. E. Jaeger, T. Darbre, J. L. Reymond, Chem. Biol. 2008, 15, 1249, https://doi.org/10.1016/j.chembiol.2008.10.009

[18] R. U. Kadam, M. Bergmann, M. Hurley, D. Garg, M. Cacciarini, M. A. Swiderska, C. Nativi, M. Sattler, A. R. Smyth, P. Williams, M. Camara, A. Stocker, T. Darbre, J. L. Reymond, Angew. Chem. Int. Ed. 2011, 50, 10631, https://doi.org/10.1002/anie.201104342

[19] R. U. Kadam, D. Garg, J. Schwartz, R. Visini, M. Sattler, A. Stocker, T. Darbre, J. L. Reymond, ACS Chem. Biol. 2013, 8, 1925, https://doi.org/10.1021/cb400303w

[20] G. Michaud, R. Visini, M. Bergmann, G. Salerno, R. Bosco, E. Gillon, B. Richichi, C. Nativi, A. Imberty, A. Stocker, T. Darbre, J.-L. Reymond, Chem. Sci. 2015, 7, 166, https://doi.org/10.1039/c5sc03635f

[21] S. Baeriswyl, S. Javor, A. Stocker, T. Darbre, J.-L. Reymond, Helv. Chim. Acta 2019, 102, e1900178, https://doi.org/10.1002/hlca.201900178

[22] R. He, I. Di Bonaventura, R. Visini, B.-H. Gan, Y. Fu, D. Probst, A. Luscher, T. Kohler, C. van Delden, A. Stocker, W. Hong, T. Darbre, J.-L. Reymond, Chem. Sci. 2017, 8, 7464, https://doi.org/10.1039/C7SC01599B

[23] S. Baeriswyl, B.-H. Gan, T. N. Siriwardena, R. Visini, M. Robadey, S. Javor, A. Stocker, T. Darbre, J.-L. Reymond, ACS Chem. Biol. 2019, 14, 758, https://doi.org/10.1021/acschembio.9b00047

[24] S. Baeriswyl, H. Personne, I. Di Bonaventura, T. Köhler, C. van Delden, A. Stocker, S. Javor, J.-L. Reymond, ChemRXiv 2021, https://doi.org/10.26434/chemrxiv.14052293.v2.
[25] N. Maillard, R. Biswas, T. Darbre, J.-L. Reymond, ACS Comb. Sci. 2011, 13, 310, https://doi.org/10.1021/co200006z

[26] V. S. Fluxa, N. Maillard, M. G. Page, J. L. Reymond, Chem. Commun. 2011, 47, 1434, https://doi.org/10.1039/C0CC04670A

[27] M. Stach, N. Maillard, R. U. Kadam, D. Kalbermatter, M. Meury, M. G. P. Page, D. Fotiadis, T. Darbre, J.-L. Reymond, MedChemComm 2012, 3, 86, https://doi.org/10.1039/C1MD00272D

[28] M. Stach, T. N. Siriwardena, T. Kohler, C. van Delden, T. Darbre, J. L. Reymond, Angew. Chem. Int. Ed. 2014, 53, 12827, https://doi.org/10.1002/anie.201409270

[29] B.-H. Gan, T. N. Siriwardena, S. Javor, T. Darbre, J.-L. Reymond, ACS Infect. Dis. 2019, 5, 2164, https://doi.org/10.1021/acsinfecdis.9b00299

[30] B.-H. Gan, X. Cai, S. Javor, T. Köhler, J.-L. Reymond, Molecules 2020, 25, 5643, https://doi.org/10.3390/molecules25235643

[31] F. B. Jeddou, L. Falconnet, A. Luscher, T. Siriwardena, J.-L. Reymond, C. van Delden, T. Köhler, Antimicrob. Agents Chemother. 2020, 64, https://doi.org/10.1128/AAC.02040-19.

[32] T. N. Siriwardena, M. Stach, R. He, B.-H. Gan, S. Javor, M. Heitz, L. Ma, X. Cai, P. Chen, D. Wei, H. Li, J. Ma, T. Köhler, C. van Delden, T. Darbre, J.-L. Reymond, J. Am. Chem. Soc. 2018, 140, 423, https://doi.org/10.1021/jacs.7b11037

[33] T. N. Siriwardena, A. Capecchi, B. H. Gan, X. Jin, R. He, D. Wei, L. Ma, T. Kohler, C. van Delden, S. Javor, J. L. Reymond, Angew. Chem. Int. Ed. 2018 57, 8483, https://doi.org/10.1002/anie.201802837

[34] T. N. Siriwardena, A. Lüscher, T. Köhler, C. van Delden, S. Javor, J.-L. Reymond, Helv. Chim. Acta 2019, 102, e1900034, https://doi.org/10.1002/hlca.201900034

[35] T. N. Siriwardena, B.-H. Gan, T. Köhler, C. van Delden, S. Javor, J.-L. Reymond, ACS Cent. Sci. 2021, 7, 126, https://doi.org/10.1021/acscentsci.0c01135

[36] G. A. Eggimann, S. Buschor, T. Darbre, J. L. Reymond, Org. Biomol. Chem. 2013, 11, 6717, https://doi.org/10.1039/C3OB41023D

[37] G. A. Eggimann, E. Blattes, S. Buschor, R. Biswas, S. M. Kammer T. Darbre, J. L. Reymond, Chem. Commun. 2014, 50, 7254, https://doi.org/10.1039/C4CC02780A

[38] A. Kwok, G. A. Eggimann, J.-L. Reymond, T. Darbre, F. Hollfelder, ACS Nano 2013, 7, 4668, https://doi.org/10.1021/nn400343z

[39] A. Kwok, G. A. Eggimann, M. Heitz, J. L. Reymond, F. Hollfelder, T. Darbre, ChemBioChem 2016, 17, 2223, https://doi.org/10.1002/cbic.201600485

[40] M. Heitz, S. Javor, T. Darbre, J.-L. Reymond, Bioconjugate Chem. 2019, 30, 2165, https://doi.org/10.1021/acs.bioconjchem.9b00403

[41] M. Heitz, S. Zamolo, S. Javor, J.-L. Reymond, Bioconjugate Chem. 2020, 31, 1671, https://doi.org/10.1021/acs.bioconjchem.0c00231

[42] S. J. Zamolo, T. Darbre, J.-L. Reymond, Chem. Commun. 2020, 56, 11981, https://doi.org/10.1039/D0CC04750C

[43] X. Cai, S. Javor, B.-H. Gan, T. Köhler, J.-L. Reymond, Chem Commun 2021, https://doi.org/10.1039/D1CC01838H.

[44] A. Capecchi, J.-L. Reymond, Med. Drug Discovery 2021, 9, 100081, https://doi.org/10.1016/j.medidd.2021.100081.

[45] X. Jin, M. Awale, M. Zasso, D. Kostro, L. Patiny, J. L. Reymond, BMC bioinformatics 2015, 16, 339, https://doi.org/10.1186/s12859-015-0776-9

[46] A. Capecchi, M. Awale, D. Probst, J. L. Reymond, Mol. Inf. 2019, 38, 1900016, https://doi.org/10.1002/minf.201900016

[47] A. Capecchi, D. Probst, J.-L. Reymond, J. Cheminf. 2020, 12, 43, https://doi.org/10.1186/s13321-020-00445-4

[48] A. Capecchi, X. Cai, H. Personne, T. Köhler, C. van Delden, J.-L. Reymond, ChemRXiv 2021, 10.26434/chemrxiv.14233418.v1

[49] I. Di Bonaventura, X. Jin, R. Visini, D. Probst, S. Javor, B. H. Gan, G. Michaud, A. Natalello, S. M. Doglia, T. Kohler, C. van Delden, A. Stocker, T. Darbre, J. L. Reymond, Chem. Sci. 2017, 8, 6784, https://doi.org/10.1039/C7SC01314K

[50] I. Di Bonaventura, S. Baeriswyl, A. Capecchi, B.-H. Gan, X. Jin, T. N. Siriwardena, R. He, T. Kohler, A. Pompilio, G. Di Bonaventura, C. van Delden, S. Javor, J.-L. Reymond, Chem. Commun. 2018, 54, 5130, https://doi.org/10.1039/C8CC02412J

\section{License and Terms}

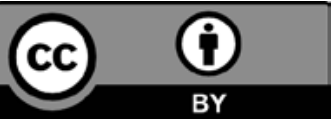

This is an Open Access article under the terms of the Creative Commons Attribution License CC BY 4.0. The material may not be used for commercial purposes.

The license is subject to the CHIMIA terms and conditions: (http:// chimia.ch/component/sppagebuilder/?view=page\&id=12).

The definitive version of this article is the electronic one that can be found at https://doi.org/10.2533/chimia.2021.535 